\title{
APPLICATION OF LIQUID EXTRACTION FOR TREATMENT OF WASTEW ATER FROM EDIBLE OILS PRODUCTION
}

\author{
Vasyl Dyachok $^{1, *}{ }^{,}$Anastasia Marakhovska ${ }^{1}$, Svitlana Marakhovska ${ }^{1}$
}

https://doi.org/10.23939/chcht12.01.114

\begin{abstract}
The structure of an emulsion formed in wastewater from edible oils production has been investigated. The type of emulsifier has been determined and the method of emulsion destruction has been proposed, providing further quality treatment of wastewater via liquid-extraction method. The resulting equilibrium and operating lines of the process were received. The number of transfer stages has been determined. The mathematical model of liquid-extraction wastewater treatment was built. Its solution allows to predict the kinetics of wastewater extraction when implementing the technology in practice. The equipment was selected to design flowsheet of wastewater treatment using a liquid extraction.
\end{abstract}

Keywords: liquid extraction, extractant, rafinate, extract, wastewater, mass transfer coefficient, diffusion, mathematical model, kinetics.

\section{Introduction}

To date the growth in capacity of enterprises producing edible oils results in the formation of huge amounts of wastewater from the production processes $[1$, 2]. The main pollutants are organic matters of mostly fat character which are impossible to be treated by existing treatment plants according to the sanitary requirements. These organic pollutants consist of neutral fats, phospholipids, organic acids and other substances of organic origin. They are insoluble in water and form stable emulsions, which in their turn, contribute to the accumulation of significant amounts of mechanical contaminants in the form of suspended matters. Many of the known treatment methods are ineffective, and some of them cause additional pollution of water. This creates a significant environmental problem because it causes pollution of surface waters by organic substances. The main source of the pollutants is wastewater from edible

\footnotetext{
${ }^{1}$ Lviv Polytechnic National University,

12, S.Bandery St., 79013 Lviv, Ukraine

dyachokvasil@gmail.com

(C) Dyachok V., Marakhovska A., Marakhovska S., 2018
}

oils production. The pollutants cause decay and blooming processes, infection by bacteria, and ultimately have a negative impact on fauna and flora [2-10]. For many enterprises of the industry the proper treatment of wastewater is a serious problem. The development of treatment technology for wastewater from edible oils production, which would give an opportunity to solve the problem of reducing contamination of the environment and could be implemented within a wide variety of wastewater compositions, is an urgent task.

So, the aim of this work is to study the liquid extraction as an effective way to remove pollutants from wastewater of edible oils production. On the basis of experimental results we propose the equipment for efficient treatment.

\section{Experimental}

Identification of main pollutants was carried out using chromatography, namely a thin layer chromatographic method over silica "H" plates ("Merck" company, layer thickness $0.3 \mathrm{~mm}$.) Chromatography was performed by two directions: $1^{\text {st }}$ direction: chloroformmethanol-25\% aqueous solution of ammonia (65:25:2 $\mathrm{v} / \mathrm{v}) ; 2^{\text {nd }}$ direction: chloroform-methanol-acetic acidwater $(65: 15: 10: 3 \mathrm{v} / \mathrm{v})$. Phospholipides were visualized as yellow spots over the plates due to iodine vapors [11].

The process of liquid extraction from the multicomponent system proceeded by direct contact of two liquid phases. The kinetics was studied at different speeds of the mixer. The experimental procedure is the following: wastewater and extractant with the ratio of $1: 1 \mathrm{v} / \mathrm{v}$ were mixed in the mixer for $30 \mathrm{~min}$, then after settling two layers (extract and rafinate) were obtained. The concentration of the pollutants in wastewater was determined by a photocolorimetry. The essence of the method is light absorption by pollutant in the visible spectrum at a wavelength of $490 \mathrm{~nm}$. For this purpose the calibration graph was built using pre-known values of conventional pollutants concentrations. Then the concentrations of actual pollutants in the water layer and extractant after liquid extraction were determined. 


\section{Results and Discussion}

The studied wastewater is a microheterogeneous system that can be described as an emulsion in which the dispersed phase and dispersion medium are in a liquid state. Such systems can long exist only in case that they are formed by liquids and are not dissolved in each other. In this case, the stability of such emulsions is provided by a ratio of phase densities. A density of dispersion medium is close to the density of the dispersion phase, so this emulsion is stable in terms of sedimentation. This was confirmed experimentally; the emulsion is stored for a long time in the field of gravity forces, centrifugal forces and while standing. Centrifugation at $3000 \mathrm{rev} / \mathrm{min}$ for $20 \mathrm{~min}$ did not give the desired result that indicates the inefficiency of mechanical treatment methods of wastewater with such properties.

Using methylene blue dye and further microscoping we found that this emulsion is of the first type, because colorless beads are observed on a blue background which can be identified as oils. These emulsions are also called direct emulsions, i.e. oil emulsions in water, where the nonpolar or weakly polar dispersed phase is located in a highly polar dispersion medium. According to another classification this is a concentrated emulsion because the dispersed phase occupies more than $0.1 \%$ of the total volume of the emulsion $[12,13]$.

It was important to investigate what kind of surfactants in water can act as emulsifiers. It is known from the literature that phospholipids which are byproducts of edible oils [14] may be good emulsifiers. Their amount in oil varies depending on the production technology. The higher concentration of phospholipids in oils, the higher concentration of them in wastewater, and this complicates the process of wastewater treatment.

Using chromatography we identified the following phospholipids in the studied wastewater: lisophosphatidylcholine, phosphatidylcholine, phosphatidylinositol, phosphatidylserine, phosphatidylethanolamine, phosphatidylglycerol, phosphatidic acids, lisophosphatidylethanolamine, minoglycosides digliceride, neutral lipids. So, it is assumed that phospholipid compounds of a diphyl structure, in which an ammonium cation is basic for polar part, are emulsifiers in this system.

Surrounded by water phospholipid molecules have the ability to be organized in such a way that the hydrophilic "heads" are directed outside and contact with water; the "tails" are directed inward and contact only with the tails of neighboring phospholipids. Thus micelles- small spherical particles - are formed. Most probably, such structure causes extreme resistance, which greatly complicates the search for effective and, most importantly, safe methods of wastewater treatment.
Obviously, the presence of phospholipids, which were identified by chromatography, causes the formation of stable emulsions.

It was necessary not only to study the structure of the emulsion dispersed phase, but to find effective methods of its destroying, as well. The process of destruction is more complicated than the process of emulsion formation. It is realized, as a rule, using chemical, electrochemical or electromechanical methods.

Chemical methods involve chemicals which are often additional pollutants, and are undesirable. Therefore it is necessary to use reagents capable to form simple and safe substances, and cause the so-called phase reversibility: dispersed phase is transformed into a dispersion medium, and vice versa. This phenomenon may occur when substances, that can change the nature of the emulsion, are introduced into it. So the emulsion destruction is an integral part of wastewater treatment.

According to the experimental results the chemicals that can destroy the emulsion are oxidants, including hydrogen peroxide, sodium hypochlorite, sulfuric acid and others. Hydrogen peroxide was found to be the best. In the acidic environment hydrogen peroxide oxidizes the polar part of phospholipid molecules, destroys their surface activity, and finally destroys the emulsion. As a result of wastewater treatment by hydrogen peroxide we observed the formation of two layers (water - oil), and their subsequent separation. Cavitation and ultraviolet radiation also contribute to the emulsions destruction. During cavitation hydrogen peroxide is additionally formed in water, and intensifies the process of the emulsion destruction.

To neutralize the system it is proposed to use calcium carbonate because the reaction product is carbon dioxide, which improves a phase separation. In addition, when applying hydrogen peroxide, oxygen is evolved and also improves the phase separation [15].

Thorough analysis of physical and chemical methods of wastewater treatment used after the emulsions destruction shows the liquid extraction to be the most appropriate method for the final disposal of pollutants [16-18, 21].

To achieve the maximum efficiency of wastewater treatment it is important to choose the extractant. Extractant should have selective solubility with respect to pollutants. Extractive properties can be enhanced by mixing different extractants that form complexes in the mixture. Among possible extractants are benzene, toluene, petroleum ether, halogen aliphatic hydrocarbons. However, the toxicity of extractants does not allow them to be applied. The most promising in terms of toxicity are esters of acetic acid, ethyl acetate and butyl acetate in particular. Moreover, it was found that a substantial increase in extractive properties of ethyl acetate and butyl 
acetate is achieved by mixing them with alcohol (methanol, ethanol, propanol, butanol, isobutanol). The extraction efficiency of the mixture ethyl acetate-alcohol and butyl acetate-alcohol is significantly higher during the extraction of pollutants from oil production wastewater than in the case of using pure extractants separately.

One of the conditions of applying liquid extraction is phase separation after extraction. It is important the alcohols, which are well soluble in water to increase the extraction ability of the extractant, do not dissolve the phases. For such purposes we used three-dimentional diagram of the test solutions to determine the maximum concentration of corresponding alcohol in the mixture [18, 19]. According to $[19,20]$ the maximum allowable concentration of alcohol is about $20 \%$. It was found by the experiments that the increase in molar mass of alcohol added to the extractant, increases the extraction efficiency (Figs. 1, 2). The reason is the reduction of alcohol solubility in water with an increasing molar mass and the increase in solubility of organic wastewater pollutants such as glycerides, phosphatides and neutral fats in extractant.

It should be noted that the increase in alcohol molar mass increases the concentration of pollutants passed into the extractant. Among listed alcohols, butanol was found to be the most effective one (Figs. 1,2).

Distribution of the target component between liquid phases is determined by the conditions of

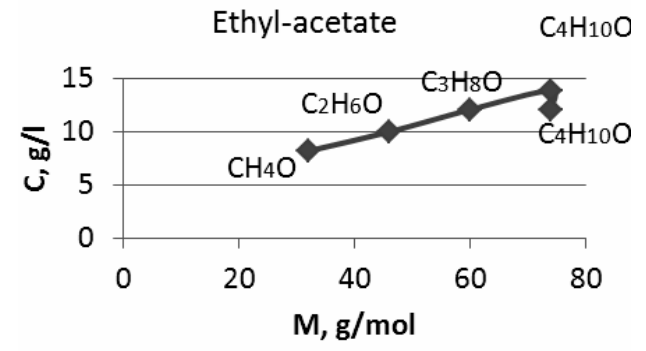

Fig. 1. Pollutant concentration in the extractant (mixture with ethyl acetate) $v s$. molar mass

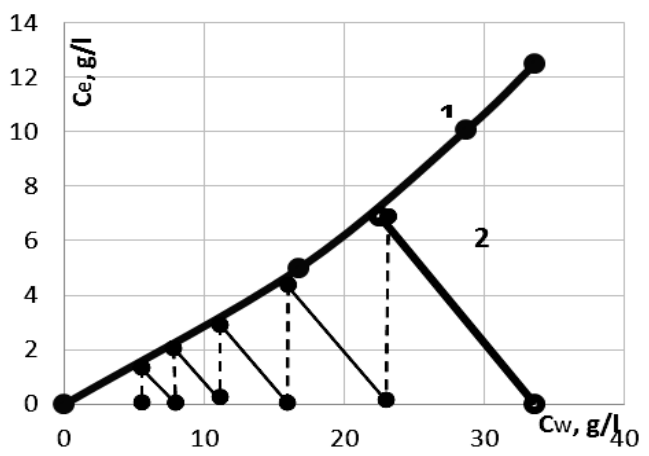

Fig. 3. Equilibrium line (1) and operating line (2) for ethyl acetate; batch process equilibrium. If we do not take into account the mutual solubility of the phases, the equilibrium conditions are determined by a straight line equation $y=k x$, where $y$ - the concentration of the target component in the extract; $x$-its concentration in wastewater; $k$ - coefficient of distribution. According to the distribution law, at a constant temperature the coefficient $k$ is constant. In fact, it depends on many factors: temperature, pressure, substances nature, concentration, etc. Therefore, the equilibrium line in $x-y$ coordinates under the studied conditions takes the form of the curve shown in Figs. 3 and 4. The coefficient of distribution is not constant [17, 18].

The next step was to study the operating line of the process. The line shows the concentration of pollutant in wastewater after reaching equilibrium. Figs. 3 and Fig. 4 show the equilibrium and operating lines for ethyl acetate and butyl acetate, respectively, as well as the purification efficiency within the given initial and final concentrations of two liquids. As seen from the figures, seven-fold reduction of the pollutants concentration in wastewater demands five transfer stages in the case of ethyl acetate (Fig. 3), and twice more in the case of butyl acetate (Fig. 4).

Among a variety of liquid extraction apparatuses that can be recommended for the treatment of wastewater from edible oils production, counter-current columns with a mechanical stirring (vibrating, rotary-disc, pulsating) are the most rational ones. If the counter-current scheme is used for liquid extraction the number of transfer stages is significantly reduced (Figs. 5, 6).

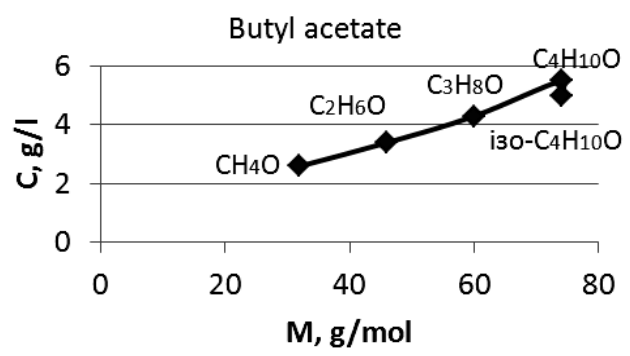

Fig. 2. Pollutant concentration in the extractant (mixture with buthyl acetate) $v s$. molar mass

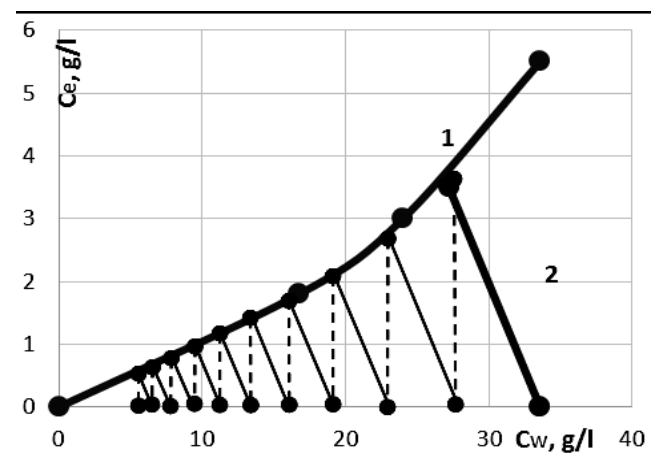

Fig. 4. Equilibrium line (1) and operating line (2) for buthyl acetate; batch process 


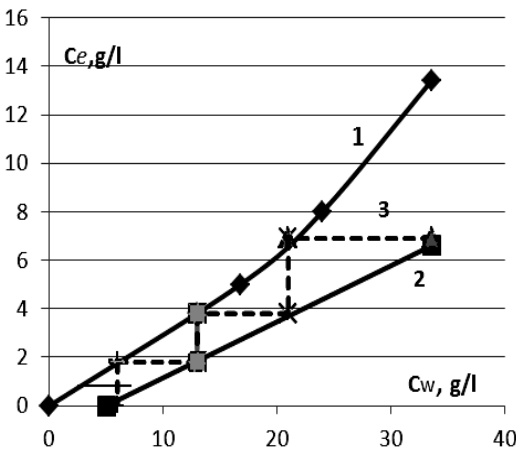

Fig. 5. Equilibrium line (1), operating line (2) and number of transfer stages (3) for ethyl acetate; counter-current process

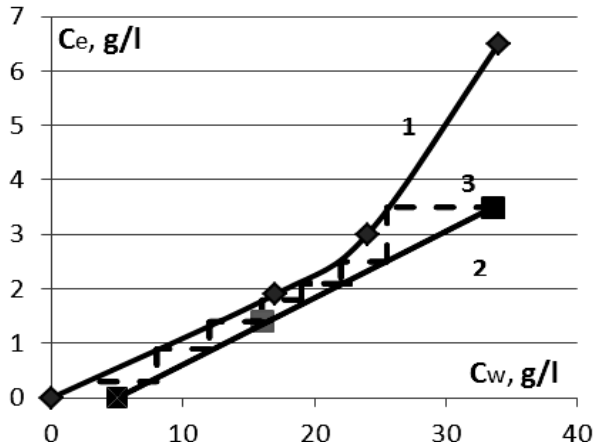

Fig. 6. Equilibrium line (1), operating line (2) and number of transfer stages (3) for buthyl acetate; counter-current process

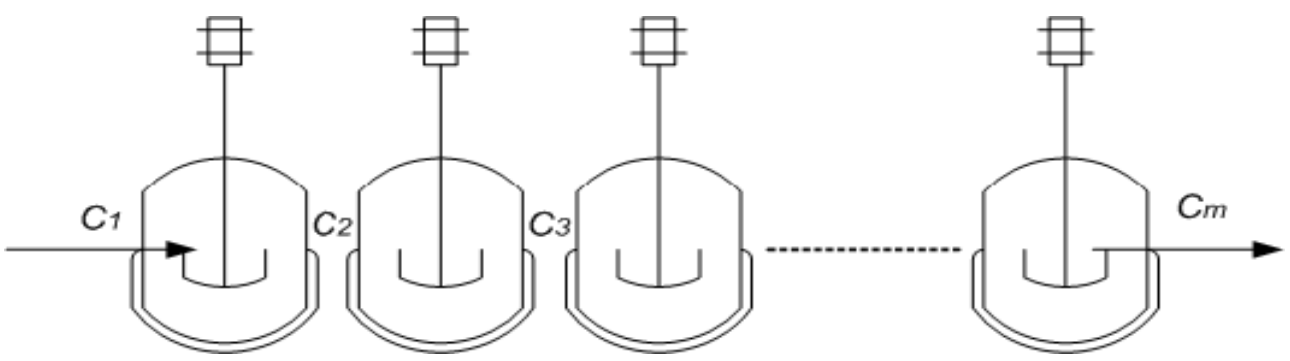

Fig. 7. Scheme of mixing-settling extractors

Mathematical models of liquid extraction in the perforated-plate column are already known [21].

However, when we need an apparatus equivalent to a high number of theoretical stages of mass transfer (Figs. $3,4)$, and have to strongly control and correlate the concentration and composition of the extract on the individual stages of mass transfer the mixing-settling extractors should be used.

The mathematical description of the mixingsettling extractor $[22,23]$ can be represented by the model with specific characteristics. The entire volume of the apparatus or their system is represented as an individual extractor. All extractors are connected in series. Ideal mixing occurs in each extractor and is lacking between them. It is represented in Fig. 7, where $C_{1}, C_{2}, C_{3}-$ concentrations in 1,2, 3 extractors, respectively; $C_{m}-$ concentration in " $m$ " extractor.

Since ideal mixing occurs in each extractor and output of the previous apparatus is the input for the next, it is possible to write a system of mathematical equations:

$$
\left\{\begin{array}{l}
\frac{d C_{1}}{d \tau}=\frac{C_{i n}-C_{1}}{\tau_{1}} \\
\frac{d C_{2}}{d \tau}=\frac{C_{1}-C_{2}}{\tau_{2}} \\
\hdashline \frac{d C_{m}}{d \tau}=\frac{C_{m-1}-C_{m}}{\tau_{m}}
\end{array}\right\}
$$

In the system of " $m$ " equations where $m$ - number of extractors; $\tau_{1}, \tau_{1}, \ldots, \tau_{m}$ - holding time of flow in the first, second, ..., last extractor. The system is a mathematical description of the liquid extraction process in the system of mixing-settling extractors.

The basic model parameter is a number of extractors $m$. Its value varies according to the number of theoretical transfer stages. The smallest value is 1 . In such a case, only the first equation is in the system (1). So, we get one limiting case - one limiting structure - ideal mixing. If the number $m$ increases then we consider the transfer function.

Let us analyze if $m=2$. The model converts into Eq. (2):

$$
\left\{\begin{array}{l}
\frac{d C_{1}}{d \tau}=\frac{C_{i n}-C_{1}}{\tau_{1}} \\
\frac{d C_{2}}{d \tau}=\frac{C_{1}-C_{2}}{\tau_{2}}
\end{array}\right\}
$$

When using Laplace transform [24]:

$$
\left\{\begin{array}{l}
\rho C_{1}(\rho)=C(\rho)_{\text {in }}-C_{1}(\rho) \\
\rho C_{2}(\rho)=C_{1}(\rho)-C_{2}(\rho)
\end{array}\right\}
$$

or

$$
\left\{\begin{array}{l}
C_{1}(\rho)\left(1+\rho \tau_{1}\right)=C(\rho)_{\text {in }} \\
C_{2}(\rho)\left(1+\rho \tau_{2}\right)=C_{1}(\rho)
\end{array}\right\}
$$

Since $C_{2}(\rho)=C_{2}(\rho)_{o u t}$, on the basis of Eq. (4) we obtain: 


$$
w(\rho)=\frac{C_{(\rho) \text { out }}}{C_{(\rho) \text { in }}}=\frac{1}{\left(1+\rho \tau_{1}\right)\left(1+\rho \tau_{2}\right)}
$$

This model can be applied if all cells have the same volume. Then Eq. (5) has a form:

$$
\frac{C_{(\rho) \text { out }}}{C_{(\rho) \text { in }}}=\frac{1}{\left(1+\frac{\rho \tau}{2}\right)^{2}}
$$

Since $\tau=\tau_{1}+\tau_{2}$, for $m$ cells we obtain:

$$
w(\rho)=\frac{1}{\left(1+\frac{\rho \tau}{m}\right)^{m}}
$$

Eq. (7) is a transfer function of the developed model. We use a substitution:

$$
\frac{\rho \tau}{m}=\frac{1}{x}
$$

Then

$$
m=\rho \tau x
$$

Let us evaluate the limit based on Eq. (8):

$$
\lim _{m \rightarrow \infty} \frac{1}{\left(1+\frac{\rho \tau}{m}\right)^{m}}=\lim _{x \rightarrow \infty} \frac{1}{\left(1+\frac{1}{x}\right)^{\rho \tau x}}
$$

Since $\lim _{x \rightarrow \infty}\left(1+\frac{1}{x}\right)^{x}=e$, then

$$
\lim _{m \rightarrow \infty} \frac{1}{\left(1+\frac{\rho \tau}{m}\right)^{m}}=e^{-\rho \tau}=\frac{C_{\rho(\text { out })}}{C_{\rho(\text { in })}}
$$

It means that very large values of $m$ lead to the model of the ideal displacement:

$$
\frac{C_{\text {out }}}{C_{\text {in }}}=e^{-\rho \bar{\tau}}
$$

It should be taken into account that the volume of the reactor or reactors system is constant. Increasing the number of reactors the reactor volume decreases. It follows from above-mentioned that the proposed model, due to the value of the main parameter $m$, can estimate the whole range of flow intermediate structures between two limiting cases. Moreover, the greater value of $m$, the greater influence of the displacement factor and the weaker influence of the transfer factor.

The model final decision is:

$$
\frac{C}{C_{\max }}=A e^{-\rho \bar{\tau}}
$$

or

$$
\frac{C}{C_{\max }}=A e^{-\frac{D t}{R^{2}}}
$$

where $C$ - current value of extract concentration; $C_{\max }-$ final value of extract concentration.
After taking the logarithm Eq. (14) has a form:

$$
\ln \frac{C}{C_{\max }}=\ln A-\frac{D t}{R^{2}}
$$
coordinates:

This equation describes the straight line in the

$$
\begin{gathered}
\ln \frac{C}{C_{\max }}=\int(t) \\
\operatorname{tg} \alpha=\frac{D}{R^{2}}
\end{gathered}
$$

Now it is possible to determine the diffusion coefficient $D$ if we know the drop radius $R$.

The drop radius is calculated according to the formula [25]:

$$
R=\frac{d_{k}}{2}=\sqrt{\frac{2 \delta}{g \Delta \rho}}
$$

where $\delta$ - coefficient of surface tension for a water drop; $g$ - acceleration of gravity; $\Delta \rho$ - difference between density of liquids (wastewater and extractant).

Density is calculated according to Eq. (19):

$$
\frac{1}{\rho}=\frac{x_{1}}{\rho_{1}}+\frac{x_{2}}{\rho_{2}}
$$

where $\rho$ - density of the mixture (extractant); $\rho_{1}, \rho_{2}-$ densities of the organic solvents; $x_{1}, x_{2}$-mass parts of the organic solvents.

The diameters of ethyl acetate and butyl acetate drop were $0.635 \cdot 10^{-3}$ and $0.68 \cdot 10^{-3} \mathrm{~m}$, respectively. Since the drop size is small, we may assume the absence of convective component at determination of diffusion coefficient for the main pollutants in water. Taking into account the predicted conditions (15)-(17), we obtained the straight lines 1-3 (Fig. 8).

After calculations the order of diffusion coefficient was found to be $10^{-9} \mathrm{~m}^{2} / \mathrm{s}$.

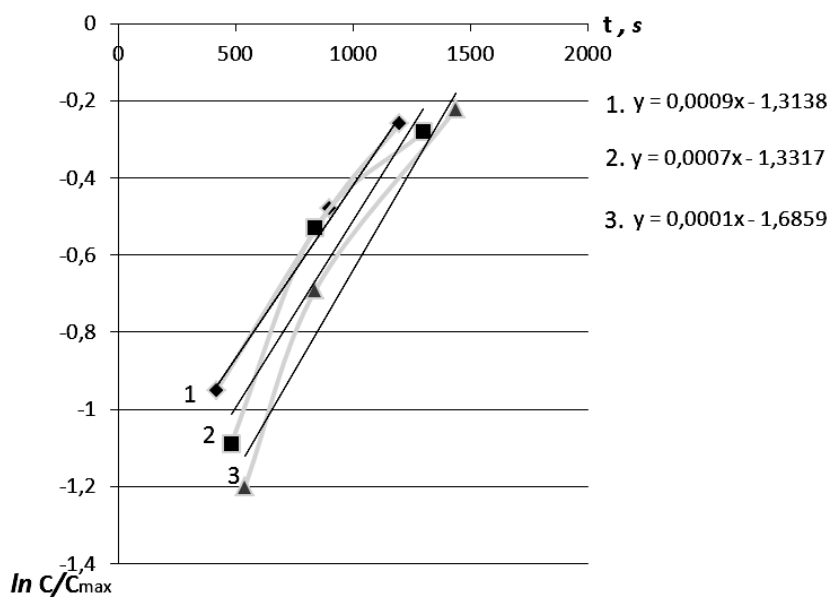

Fig. 8. Kinetics of wastewater treatment using liquid extraction in the mixing-settling extractor at mixer different speeds (rev/min): 12 (1); 8 (2) and 4 (3) 


\section{Conclusions}

The structure of surfactants which act as emulsifiers during formation of stable emulsions in wastewater from edible oils production was specified. We propose an environmentally friendly method of their destruction, providing the appropriate level of wastewater treatment in the industry. A mixture of organic solvents that can be used as an extractant were selected. A mathematical model of multi-staged liquid extraction for a wastewater treatment was developed. Its solution allows to evaluate an order of diffusion coefficient of wastewater basic pollutants.

\section{References}

[1] KeeL., Lee K.: Biotechnol. Adv.,2011, 29, 124.

https://doi.org/10.1016/j.biotechadv.2010.10.001

[2] Berezutskyi V., Gorbenko V., Mezentseva I.: East-Eur. J. Adv. Technol., 2011, 6, 57.

[3] http://www.ais.unwater.org/ais/pluginfile.php/356/mod_page/ content/111/CountryReport_India.pdf

[4] Inan H., Dimoglo A, Şimşek H., Karpuzcu M.: Separ. Purif. Technol., 2004, 36, 23. https://doi.org/10.1016/S1383-

5866(03)00148-5

[5] Willey R.: Ecotox. Environ. Safe., 2001, 50, 127.

https://doi.org/10.1006/eesa.2001.2081

[6] Igwe J., Onyegbado C.: Global J. Environ. Res., 2007, 1, 54. https://idosi.org/gjer/gjer1(2).htm

[7] Singh-Nee Nigam P., Pandey A. (Eds): Biotechnology for AgroIndustrial Residues Utilisation: Utilisation of Agro-Residues.

Springer Science \& Business Media, 2009.

https://doi.org/10.1007/978-1-4020-9942-7

[8] Cammarota M., Freire D.: Biores. Technol., 2006, 97, 2195.

https://doi.org/10.1016/j.biortech.2006.02.030

[9] Kismurtono M., Julendra H., Mahajoeno E., Korniawan M.:

Cogeneration, Small Power Plants and District Energy (ICUE), Int.

Conf., Sep. 14, 2016, 1.

https://doi.org/10.1109/COGEN.2016.7728954

[10] Vakula Yu.: Konf. Cheshskoho Izdat. doma "Rusnauka", Praha 2014, 182071.doc.htm, 2015.

[11] Dyachok V.: PhD thesis, Lviv Polytechnic National University, Lviv, Ukraine, 1994.

[12] Tadros T. (Ed.): Emulsion Formation and Stability. John Wiley \& Sons, New Jersey 2013.

[13] Kostrzhyts'kyy A. (Ed.): Fizychna ta Koloidna Khimiya. Centre uchbovoi literatury, Kyiv 2008.
[14] Esau K.: Anatomy of Seed Plants, $2^{\text {nd }}$ edn. Wiley, New York 1977.

[15] Holodovs'ka O., Marakhovs'ka A., Dyachok V.: Pat. UA

111389, Publ. Oct. 11., 2016.

[16] Gupta V. Ali I., Saleh T. et al.: Rsc Adv., 2012, 2, 6380-8. https://doi.org/10.1039/C2RA20340E

[17] Zulkovskiy Z.: Zhidkostnaya Ekstraktsiya v Khimicheskoi Promyshlennosti. Goshimizdat, Leningrad 1972.

[18] Zapolskiy A. (Ed.): Fiziko-Khimichni Osnovy Tehnolohii Ochischennya Stichnykh Vod. Libra, Kyiv 2000.

[19] Reichardt K.: Rastvoriteli v Organicheskoi Khimii. Khimiya, Leningrad 1973.

[20] Reichardt C., Welton T.: Solvents and Solvent Effects in Organic Chemistry, $4^{\text {th }}$ edn. Wiley-VCH, Weinheim 2010. https://doi.org/10.1002/9783527632220

[21] Gasanov A.: J. Sci. Res. Develop., 2015, 9, 50.

[22] Aris R.: Mathematical Modeling: a Chemical Engineer's Perspective. Academic Press, NY 1999.

[23] Kafarov V., Glebov M.: Matematicheskoe Modelirovanie Osnovnykh Protsessov Khimicheskikh Proizvodstv. Vysshaya shkola, Moskva 1991.

[24] Doetsch G.: Introduction to the Theory and Application of the Laplace Transformation. Springer Science \& Business Media 2012.

[25] Gasanov A., Mamedov E.: Problemy Nauki, 2016, 25, 39.

Received: February 17, 2017 / Revised: September 18, 2017 / Accepted: October 29, 2017

\section{ЗАСТОСУВАННЯ РІДИННОЇ ЕКСТРАКЦІї ДЛЯ ОЧИЩЕННЯ СТІЧНИХ ВОД ВИРОБНИЦТВА ХАРЧОВИХ ОЛІЙ}

\begin{abstract}
Анотація. Досліджено структуру емульсії, яка утворюється у стічних водах виробничтв харчових олій. Встановлено вид емульгатора та запропоновано спосіб руйнування емульсії, що забезпечує в подальшому якісне очищення стічних вод олійних виробниџтв рідинноекстракційним методом. Отримана лінія рівноваги та робочі лінії процесу. Встановлено кількість ступеней переносу. Побудовано математичну модель рідинно-екстракційного очшщення стічної води. Рішення ї̈ дає можливість прогнозувати кінетику процесу екстркиійного очищення стічних вод при реалізачії технології на практиці. Підібрано обладнання для проектування технологічної схеми очшщення стічних вод виробництва харчових олій рідинною екстракиію.
\end{abstract}

Ключові слова: рідинна екстракиія, екстрагент, рафінат, екстракт, стічна вода, коефіціснт масопередачі, дифузія, математична модель, кінетика. 